\title{
The history of private international law: the theory of Belgian realism in the $16^{\text {th }}$ century
}

\begin{abstract}
This article looks at the school of Belgian realism in the $16^{\text {th }}$ century, one of the lines of thought in the theory of statues, which was the only doctrine of private international law for over 500 years. Supporters of the school of Belgian realism of the $16^{\text {th }}$ century, Nicolas Everhard, Pieter Peck, Johannes a Sande gave rise to the classical Dutch doctrine of "international comity" that underlies the Anglo-American approach to the regulation of international private relations. In the theory of statues, Belgian realism is a separate line of thought, which laid the foundation for a strictly territorial concept for the resolution of different conflicts of national laws. The article concludes that Everhard, Peck and Sande formulated connecting factors accepted by the legal systems of today. Their research served as the basis for the emergence of the doctrine of international comity and the perceived practice of modern private international law.
\end{abstract}

Keywords: Private, international, law, theory, statues, XVI century, Belgian, realism, connecting, factors
Volume 2 Issue 5 - 2018

Irina Getman Pavlova

Department of Public and Private International Law, National Research University, Russia

Correspondence: Irina Getman Pavlova, Associate professor, Department of Public and Private International Law, National Research University Higher School of Economics, Candidate of Sciences $(\mathrm{PhD})$ in Law, Moscow, Russia,

Email getmanpar@mail.ru, igetmanpar@hse.ru

Received: April 23, 2018 | Published: October 25, 2018

\section{Introduction}

Private International Law (PIL) "in our era is national law and its sources made up of laws, customs and precedent. At its inception, Private International Law originated as a higher national law with judicial science as its source". The source of PIL and its alwaysimportant doctrine was established a few centuries earlier than national law as a solution to regulate private legal relationships associated with foreign law. Today, PIL remains one of the more scientifically oriented fields of law. As Russian researcher, L. Luntz once wrote, "references to theoretical writings on private international law are far more prevalent in court decisions than the discussions by courts of any other field of law. In private international law the difficulties in solving a wide range of issues and gaps in legislation of almost every nation is so great that in PIL rather than any other field of law, the study of the work of legal theorists is needed and important not only theoretically but also practically". ii

In Russian legal literature of the $20^{\text {th }}$ century, it is mentioned that PIL originated "in the $13^{\text {th }}$ century, first as a theory, more specifically, the theory of statues and was further developed by legal scholars, an opinion courts have adopted".iii Over the course of 500 years, the theory of statues was the only doctrine of PIL, which can be considered the first attempt at a scientific formulation and systemization of the fundamentals of PIL" iv Rejection of this theory did not occur until the $19^{\text {th }}$ century through the writings of scholars, but almost immediately a school of "neo-statutists" arose whose views were largely based on the classic theory of statues. Furthermore, the theory of statues over the course of the $19^{\text {th }}$ and parts of the $20^{\text {th }}$ centuries was widely accepted as the basis of literature and significantly influenced the development of the legislation of private international law. "Mention of personal

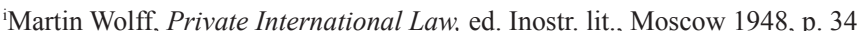
iiLasar' Lunts, ${ }^{1}$ Kurs mezhdunarodnogo chastnogo prava, V 3 t. T. I, ed. Spark, Moscow 2002, p. 68.

iii Fedor Sadovsky, Osnovy chastnogo mezhdunarodnogo prava i primenenie ih v oblasti nasledovaniya, Journal Ministerstva justicii, 9 (1903), p. 13.

${ }^{i v}$ See: Fedor Martens, Sovremennoe mezhdunarodnoe pravo civilizovannyh gosudarstv, V 2 t. T. 2. St. Petersburg 1904-5, p. 296. or real statues and even the use of such terminology is inevitable, as Phillimore among others has confessed, having understood the serious shortcomings of past statute theory; and sometimes volens-nolens and Bar himself, the most powerful opponents against the remnants of medieval private international law doctrine fall back on the usage of statue terminology".

The founders of the theory of statues, Italian and French lawyers of the XIII-XIV centuries, adapted Roman texts to the needs of contemporary society, worked out general rules, which continue to live on in the modern sense of justice, and prepared contemporaneous conflict rules. Ukrainian literature mentions that the theory of statues marked the beginning of private international law for three national schools of thought; the Italian school headed by Bartolus de Saxoferrato, which dominated until the $16^{\text {th }}$ century; the French school, which arose from the influence of the Italian school; and the Dutch school, which proclaimed the principle of territoriality from the end of the $17^{\text {th }}$ century, the effect of which was softened by the theory of comity. ${ }^{\mathrm{vi}}$ However, it seems that not only the Italian, French and Dutch schools of thought are identifiable in the theory of statues. The German schoolvii and Belgian doctrine of realism, formulated by Belgian and Dutch scientists in the XVI century also offer valuable contributions to the theory of statues. This article examines the Belgian realism theory through the works of its founders Nicolas Everhard, Pieter Peck, and Johannes a Sande.

\section{History}

The first notions about how to resolve conflict of laws were accepted by Belgian and Dutch lawyers from Italy and France. During

'Dmitry Nikol'sky, Mezhdunarodnoe pravo, St. Petersburg 1903, p. 390.

${ }^{v i}$ Alexander Merezhko,3 Nauka mezhdunarodnogo chastnogo prava: istoriya $i$ sovremennost', ed. Takson, Kiev 2006, p. 47-48.

viiFor more information see f. e.: Deutsches Internationales Privatrecht im 16 und 17. Jahrhundert. Band 2: Materialien, Übersetzungen, Anmerkungen / Hrsg v, Christian von Bar u.4 Peter Dopffel, u. Mitw. v. Hans J. Hilling. 2001. XXVI, 758 S.; Max Gutzwiller,5 Geschichte des Internationalprivatrechts, ed. Helbing \& Lichtenhahn, Basel u. Stuttgart 1977. XVIII, 326 S. 
the $12^{\text {th }}-14^{\text {th }}$ centuries, many Dutch students enrolled in Italian and French universities taking back to their homeland an "appendage" of Roman law, the theory of statues, which was formulated in the writings of Pierre ${ }^{2}$ de Belleperche, Johannes Faber, Bartolus de Saxoferrato and Baldus de Ubaldis ${ }^{\text {viii }}$ The theory of statues was taught in Louvain in 1425, when the first national university was founded, as well as in Bologna, Padua or Toulouse. Since that time, the theory of statues can be found throughout the work of Belgian and Dutch authors. In the County of Flanders, based on the idea of the universality of Roman law, Italian and French Bartolists initially recognized the extraterritorial effect of personal statues as unconditional. The unconditional priority of personal law presents itself most of all within inheritance law. The integrity principle of inheritance and the subordination of all its questions to lex personalis was fixed as law for example, in Art. 25 of the Charter of the City of Ypres (1170-1174) providing that: "All property of deceased bourgeoisie from the city of Ypres, held at the time of death, all of his estate and movable property shall be subject to law and the custom of the city where he would have been." Court practice at the time also followed this approach closely, ${ }^{\mathrm{ix}}$ confirming, at least partially the decisions of the aldermen of Saint Omer (1321 and 1333). "Real estate of a citizen of Saint Omer should be divided according to the customs of Saint Omer, even if it is located in another jurisdiction... just as the property of a citizen of Gan, even if he is an illegitimate child, should be divided according to the customs of Gan". ${ }^{x}$

The integrity of inheritance completely depends on the personal law. By a resolution of the Council of the County of Flanders (1375) any property ${ }^{\mathrm{xi}}$ "must be divided according to the home custom of the deceased, in accordance with the common law of the country". xii Lex rei sitae was not even applied in relation to inheritance law for children out of wedlock. The tendency of the Flemish authorities to personalize all laws was first noted by an obscure jurist from Bruges at the end of the $16^{\text {th }}$ century, Jacob de Cort, who wrote that the home law of the deceased should govern the entire inheritance, even if the property is situated elsewhere. In this regard, the "special theory of the Flemish as the citadel of personalization of the law"xiii is often mentioned in literature. This binding of the most recent domicile to the law encompassing all inheritance property was a unique element of city law, functioning in a special "commonwealth" of Flemish cities. "The Flemish citadel of personalization of the law" remained for the whole of the middle Ages but outside of the county of Flanders, it was short lived. In the middle Ages, the mentality of the Dutch provinces could be described as dualistic, on one hand closely resembling the provinces of Northern Italy and on the other hand, exuding a striking difference between the two. In the Netherlands (as in Lombardy) industry, trade, and statutory law were quite developed for the time leading to the need to develop specific rules to resolve conflicts between the customs of different cities. In

\footnotetext{
viiiSee: Armand Laine, ${ }^{6}$ Introduction au droit international privé, ed. Librairie Cotillon, Paris 1888, T. I, p. 396.

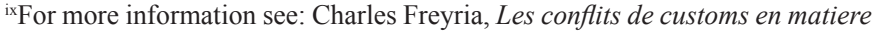
de successions dans le droit coutumier urbain des Flandres sous l'ancien regime, Rev. crit. 249 (1947).

${ }^{x}$ Bertrand Ancel, ${ }^{7}$ Histoire du droit international privé, ed. Université Panthéon-Assas (Paris II), Paris 2008, p. 84.

${ }^{x i}$ Any property means strictly real estate; movable property was not considered property until the $19^{\text {th }}$ century and was always subject to its owners personal law.

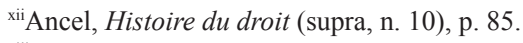

xiii Ibidem.
}

the $16^{\text {th }}$ and $17^{\text {th }}$ centuries, the Netherlands economically blossomed and as a consequence especially needed to develop regulation over private international relations. In political terms, these lands were not as free as the Italian republics; their dependence on the kings of Spain was incomparably greater than that which formally subjected Italy to the emperors of the Holy Roman Empire of the German Nation. The Netherlands was positioned within the province as an appendage of a larger state under the rule of consistently absent foreign princes replacing each other century after century. ${ }^{\text {xiv }}$ At the same time, Dutch cities were imbued with the spirit of extreme individualism ${ }^{\mathrm{xv}}$ and demonstrated a clear tendency towards feudal sovereignty of their customs. Among other elements of legal autonomy, the Dutch provinces enjoyed significant privileges and benefits. The Counties of Flanders and Zeeland, the Duchy of Brabant, the Lordship of Frisia, Utrecht, and Southern Holland, i.e. all of the northern provinces of which became the Netherlands and the southern provinces, current day Belgium, had their own customs, with roots dating back centuries. The provinces held onto their privileges as a symbol of local freedom and made vigorous efforts to preserve them. The sovereignty of the provinces was finally legally recognized in the "Close Union," signed on 23 January 1679, in Utrecht by the representatives of the Dutch Republic. ${ }^{\text {xvi }}$ The first article of the treaty declared that "although the provinces have been unified, to ensure that they remain unified for centuries to come as if they were one province, each province and city shall retain its privileges, freedoms, and customs". xvii

The desire for all of the Dutch provinces to maintain their privileges and establish their own territorial sovereignty pushed the doctrine and practice of establishing a strict imperative on the territorial character of any law. As (according to the theory of statues) only real statues had territorial force, the doctrine of conflict rules had in the $16^{\text {th }}$ century already completely established the principle that "all customs are real:" "Here is the substantive explanation of our customs, as materiality and independence of a separate territory are one in the same". ${ }^{\text {viii }}$

Modern PIL has accepted and distinguishes the Dutch theory of statues, which is known also as the "doctrine of international comity." Its main apologists were Ulricus Huber and Paul and John Voet. However, most experts on PIL who wrote in the $19^{\text {th }}$ century mention not the Dutch but the Belgian-Dutch theory of conflict of laws. ${ }^{x i x}$ This clarification is quite accurate as the classical Dutch doctrine was finally formulated at the end of the second half of the $17^{\text {th }}$ century. The Dutch doctrine was formed on the basis of the theory of Belgian realism, which originated at the end of the $16^{\text {th }}$ century within the theory of statues. Naturally, one must keep in mind that the terms "Dutch-Belgian" and "Belgian" are quite relative based on the history of the region in the $16^{\text {th }}$ century, as at that time, modern

${ }^{\text {xiv }}$ See: Laine, Introduction au droit (supra, n. 8), p. 398.

${ }^{\mathrm{xv}}$ As Belgian scholar, Laurent wrote at the end of the $19^{\text {th }}$ century, "even today a Flemish from Bruges is not sure of the fraternal bonds with a Flemish from Ghent." See: Francois Laurent. ${ }^{8}$ Droit civil international, ed. BruylantChristophe \& ce, Bruxelles 1880, T. I, p. 340.

xviThe rest of the Dutch lands gradually joined the "Close Union."

xvii Michail Brun.9 Ocherki istorii konfliktnogo prava, ed. Tipografiya G. Lissnera i D. Sobko, Moscow 1915, p. 76.

xviiiLaurent, Droit civil international (supra, n. 15), p. 425.

${ }^{x i x}$ See f. e.: Friedrich Meili. ${ }^{10}$ Civil- und Handelsrecht auf Grund der Theorie, Gesetzgebung und Praxis, I Band, hrsg. Art. Institut Orell Fussli, Zurich 1902, S. 95. This term used also Laurent and Laine: Laurent, Droit civil international (supra, n. 15), p. 442; Laine, Introduction au droit international privé (supra, n. 8), p. 396. 
Belgium and Holland did not exist, one could only speak of one of the provinces of the Netherlands. ${ }^{x x}$ The theory of Belgian realism is considered the first step in the classical Dutch doctrine. The beginning of the Belgian realism theory was established in the works of $16^{\text {th }}$ century authors, Belgian Nicolas Everhard and Dutchman Pieter Peck. The theory received its consummate expression through the works of a Dutch author of the first third of the $17^{\text {th }}$ century, Johannes a Sande. These scholars were the precursors of Nicolas Bourgundus, Paul Christianius, Peter Stokmanns and Christian Rodenbourg, whose works became the basis for the study of the classical Dutch doctrine of Ulricus Huber and Paul and John Voet. Unfortunately, the names of the pioneers of the Belgian realism theory, Everhard, Peck, and Sande have largely been forgotten in modern PIL doctrine.

Nicolas Everhard, (1473-1532) was born in Middelburg (a province of Zeeland) to a wealthy merchant family. ${ }^{\text {xxi }}$ Everhard was the first chairman of the Dutch Council of State (Raad van State), the chairman of the Great Council of the Netherlands at Mechelen (Grand Conseil de Malines) and "governed [these institutions] with much success." He is called "one of the most eminent officials ${ }^{\mathrm{xxii}}$ in Belgian literature of the 19th century. Everhard became the first Dutch lawyer whose name went down in the history of the theory of statues. His views on conflict rules enjoyed popularity and prestige among contemporaries, junior modernist and compatriot Pieter Peck "praised him to the skies and referred to the wise practitioner on issues of common marital property". xxiii The famous French scholar, Charles Dumoulin, speaking about problems of laws applicable to martial property also frequently quoted Everhard. xxiv

"Topica de locis legalibus" and "Consilia sive Responsa" are the main studies broaching the subject of conflicts of legal customs; both theses "were a great success and included many provisions about the conflict of laws" ${ }^{x x v}$ Conflicts of customs regarding joint property of spouses were considered under Topica, and under Consilia, the conflicts of customs regarding wills, transactions (a review or normative rules), and inheritance. It is impossible to say that conflict resolutions of the scholar were principally new but they gave a complete picture of the formation of the Belgian realism theory at the beginning of the $16^{\text {th }}$ century. Primarily, Everhard was a practical man and considered conflict issues from a practical point of view. According to Laine, Everhard's points of view were inspired by Bartolus de Saxoferrato and other commentators of the Cunctos populus Law. ${ }^{\text {xxi }}$

xxIn 1512, the majority of Dutch land was merged with the Burgundian Circle of the Holy Roman Empire ruled by the King of Spain; in 1549 all of the Dutch provinces entered the Burgundian Circle and from then on formed the concept of the "Seventeen Provinces of the Netherlands." It is this concept, which was widely used in the literature of the late 16th century to the beginning of the 19th century. See: Galina Shatokhina-Mordvintseva. Istoriya Niderlandov, ed. Drofa, Moscow 2007, p. 111-113.

${ }^{x x i}$ Nicolas Everhard had 6 children 2 daughters and 4 sons, "utterly erudite people." His second son, Nicolas Everhard Jr., was a doctor of Law and the chairman of the Great Council of the Netherlands at Mechelen (Grand Conseil de Malines). Everhard's youngest son was a famous Latin poet Johann Secundus. He devoted his first book (1529) to his father.

xxii Laurent, Droit civil international (supra, n. 15), p. 435.

xxiii Ibidem.

xxivSee: Franz Gamillscheg. ${ }^{11}$ Der Einfluss Dumoulins auf die Entwicklung des Kollisionsrechts, hrsg. De Gruyter: Mohr, Tubingen 1955, S. 152.

${ }^{x \times}$ Brun, Ocherki istorii (supra, n. 17), p. 64.

xxviSee: Laine, Introduction au droit (supra, n. 8), p. 396. "Cunctos populous"
Bartolist' influence also appears in the general methodology of Everhard's research just as it does in his usage of the dialectics and methods of the scholastic technique. His analysis of conflict of laws of different countries was based on the typical Bartolist method of distinction, ampliation, and limitation (distinctiones, ampliationes, limitationes). Everhard only analyzed interlocal conflict of laws arising from relations between different Dutch provinces. The main problem of true international conflict of laws could not have interested the scholar as the necessity of conflict resolution of laws of different countries arose only in the 17th century. While analyzing issues of conflicts in provincial customs, Everhard is in line with concepts established in the 14th century that all statues are divided into two groups based on their subject of regulation: personal statues, which define the legal status of people and real statues, which define the legal status of property. At the same time, the historical context impeded Everhard from accepting Bartolist universalism and its leaning towards the extraterritoriality of lex personalis. Similar to his contemporaries in France (Jean Masuere, Bartolomeus Chassnet, Andreas Tirako), Everhard gave precedence to the principle of absolute territoriality of customs. The issue of the legal state of property does not cause any doubt for Everhard and in this regard he acknowledges that there is only one general origin "Statuta realia non egrediunt statuentis territorium". ${ }^{x x v i i}$

All property rights are always subject to the law of their location (lex loci rei), it does not matter whether it is a manifestation of rights of separate property that exists in another territory or the whole set of property rights of a person on the basis of this law. When considering problems of inheritance, Everhard stated that the form of a will is governed by the law of the territory where the will was drawn up. In this sense his position reflects the Italian doctrine. However, he adheres strictly to the territorial rule, because any statute is primarily made to protect the interests of heirs and keep property in the family. Therefore, it doesn't matter whether a statute was issued prohibiting a married couple from leaving their property to each other. ${ }^{\text {xxviii }}$ If the subject of the statute is real estate, it is enough that its force was strictly territorial and applied to all people within the territory of whichever province. Everhard most elaborately examined conflict of laws regulation with regard to contractual obligations. This is no surprise considering that trade relations between provinces and trade with foreign countries were significant issues of importance for the Netherlands of the $16^{\text {th }}$ century. As with the majority of his predecessors, (Paul de Castro and Rochus Curtius) Everhard assumes that a contract must be subject to the law of the place where it was concluded (lex loci celebrati contractus). ${ }^{\text {xix }}$

The scholar views the place of contract two-fold: the place of conclusion (locus conclusionis), and the place where the contract is performed (locus solutionis). Application of the law of the place of conclusion is a general rule; however, in practice, the law of the place of performance is the most competent to apply. Envisaged repercussions

were the first words of the Constitution of Gratian, Valentinian and Theodosius "On Approval of faith in the Holy Trinity" (380) that was accompanied by the famous gloss "Quod si Bononiensis" ("About Bolognese in Modena"), which in turn commemorated the beginning of conflict of laws study.

${ }^{x x v i i}$ Real statues do not extend their effect beyond its territory.

xxviiisee: Laurent, Droit civil international (supra, n. 15), p. 437.

${ }^{x x i x}$ See: Joseph Story. ${ }^{12}$ Commentaries on the Conflict of laws, foreign and domestic, ed. Hilliard, Gray, and Company, Boston 1834, p. 249. 
of a contract are subject to the place of conclusion, while unforeseen repercussions of a contact to the law of the place of performance. If the place of performance is specified in the contract, in the event of a culpable breach by the debtor, lex loci solutionis will always be applied rather than lex loci celebrati contractus. Analyzing conflict of laws in contractual relations, Everhard uses the method that shows how deeply Bartolists influenced him. It is in these matters Everhard continuously resorts to distinctions and divisions. His discourse on enforcement of the law of the place of performance is based on the following distinction: the phrase lex loci solutionis may be understood ambiguously, as an impassive statement of where the contract must be performed or by a statement of the practical performance of the contract in accordance with the aim of the parties. ${ }^{\text {xxx }}$

Everhard conclusively favors the law of the place of effective performance, especially for unforeseen consequences. In the majority of cases, Everhard defines the place of actual performance of the contract as the place of payment. The law of the place of the payment shall apply for the payment of interest. A debtor, who neglected to perform his obligations, is automatically responsible, according to the law of the place where his debt is to be paid. This is a "special place of payment" and "interest" has its right there as "interest is the origin." Everhard was one of the first in early conflict of laws literature who expressed the idea that the "law may have an interest," in other words the application of another law is aimed at achieving the objectives of that law, which in turn reflects the policy behind the law. In the $20^{\text {th }}$ century, the idea of applying the most "interested law" was appeared in the theory of "government interest" by B. Currie, the main ideologist of the American choice of law revolution. Pieter Peck (1529-1589) was born in Zierikzee (a province of Zeeland) and died in Mechelen. ${ }^{x x i}$

He studied civil and Canon law at the University of Leuven and defended his doctorate degree in 1553 , having taught at the same university from 1555. In 1562, he earned the rank of a full professor of Roman law. Following the academic tradition of the time, he Latinized his name and in legal literature he was known as Petrus Peckius. In 1582 he became a member of the Great Council of the Netherlands at Mechelen (the chair of which was Nicolas Everhard Junior), which at the time was known as the Seventeenth Supreme Court of the United Provinces. Peck's compositions were a lucky combination of theory and practice ${ }^{\text {xxxii. }}$ One of his treaties "De testamentis conjugum" (Leuven, 1564) is characterized by a detailed summary of the majority of conflict questions. The scholar paid special attention to the problems of conflict of laws in deeds of gifts between husband and wife. Peckius perceived Nicolas Everhard Sr. as his teacher and followed his views in terms of Bartolo's theory about conflict of laws. Peckius calls Bartolo and Baldus de Ubaldus the "principles juris magistri" and along with them, Peckius "was known as an admirer of Roman law". xxxiii

However, Bartolo and his followers affirmed the real nature of

\footnotetext{
${ }^{\mathrm{xx}}$ Ibidem.

xxxiPieter Peck was married to Katarina Gillis, who was a sister of the Secretary of Margaret of Parma and the Governor of Ostend. One of his sons, Petrus Peckius Jr. was also a famous lawyer, diplomat, member of the Great Council of the Netherlands at Mechelen (Grand Council de Malines) and the Chancellor of Brabant.

xxxii Laurent, Droit civil international (supra, n. 15), p. 434-435.

xxxiii Ibid. P. 435
}

prohibitive statues and that personal statues (as a general rule) were seen as permissible and had an exterritorial character to them. This approach in large part was based on the unconditional priority of Roman law, which had always been favorable up to that point. Despite his esteem for Roman law, Peck did not recognize its universalism just as respect for Bartolo did not encourage the Dutch scholar to accept the theory of permissive and prohibitive statues. Despite the fact that Peck distanced himself from the Italian school, he used its methodology and criteria. The statute, which stated that a wife does not have testamentary capacity without the consent of her husband, from his point of view was favorable. This statute would extend to any acts, even those committed abroad. The basis for the favorable nature and extraterritorial attribute, Peck finds in common (natural) law, which has priority over lex loci actus. On the other hand, a statute prohibiting inheritance between spouses is of an odious character and cannot extend its applicability abroad. To prove the odious nature of this statute, Peck refers not only to several decisions from the Great Council of Mechelen but also to the opinions of the Italian school, namely Alexander Tartagnus and Charles du Moulin. ${ }^{\text {xxiv }}$

Peck was well aware of the works of Bartolo's French followers of which, Bartholomeus Chassne, Andreas Tirako, and Charles $\mathrm{du}$ Moulin are frequently quoted. Laine wrote that "Peck is clearly familiar with d'Argentré. ${ }^{\mathrm{xxx}}$ Perhaps this is true, but it is worth noting that the famous book by d'Argentréxxxi that "revolutionized" modern conflict rules was written in 1576 and published in 1585. At the same time, Peck's final tractate was dated 1582 and his works on conflict of law were written almost 20 years before. It would seem logical to assume that Peck's views on conflicts between customs formed without any influence from the "Breton commentator"xxxvii. Peck's concept of absolute territoriality of all customs formed naturally given the historical circumstances of the era and the concept of Belgian realism was reflected in court decisions of the time. In particular, Peck asserts that the Great Council repeatedly and strictly restricted the territorial effect of the testamentary legate between husband and wife and that such decisions were just. ${ }^{\text {xxviii }}$

Peck's views on conflict rules were deeply imbued with territorialism. For example, he was so convinced of the materialism of the statute on matrimonial property that he saw no need to even mention this topic. Perhaps, his reasoning makes this impression, because he rarely mentions the status of persons or contractual relations, his entire focus is on conflict rules regarding property. Any time a question arises with regard to property, Peck referred to lex rei sitae. If the property is the subject of the statute, it is enough to call this statute real. From the minute a question of property is raised, the statute must be considered real even if there is a dispute over the properties and condition of people, their capacity, incapacity, or age. There is no need to question the main purpose of the statute, in personam or in rem, only the property is of interest. It doesn't matter whether the consequences of applying the statute are alienation or transfer of the property, it will still be real and the local custom must

\footnotetext{
${ }^{\text {xxiv }}$ See.: Gamillscheg, Der Einfluss Dumoulins (supra, n. 24), S. 151-152.

${ }^{\mathrm{xxx}}$ Laine, Introduction au droit (supra, n. 8), p. 397.

${ }^{\text {xxxvi} B e r t r a n d ~ d ' A r g e n t r e ́ . ~ C o m m e n t a i r e ~ d e s ~ c u s t o m s ~ d e ~ B r e t a g n e, ~ P a r i s, ~} 1621$

xxxviiBertrand d'Argentré is called as such in PIL. See f. e.: Andrey14 Mandel'shtam. Gaagskiye konferentsii o kodifikatsii mezhdunarodnogo chastnogo prava, T. I. St. Petersburg 1900, p. 89.

xxxviii See: Laurent, Droit civil international (supra, n. 15), p. 435.
} 
be adhered to. ${ }^{\text {xxxix }}$

Joannes à Sande was born on 28 June 1568 in Arnhem (the province of Gelderland and died on 17 November 1638 in Leeuwarden (the province of Friesland). He studied history and law in the universities of Wittenberg and Leiden. From 1598 to 1604, he served as professor of law at a university in Franeker, and later was a member and justice of the Court of Friesland. His main study, which opens the subject of conflict of law, is "Decisiones aureae sive Frisiorum curia judicatarum" (Leuvarden, 1635). This is a broad tractate on the current law of Friesland illustrated by frequent legal practice and quotes from studies of a range of famous European lawyers. Sande's research was one of the most significant works of the 17th century. Joannes à Sande was Ulrich Huber's "favorite author," who was one of the most outspoken of the Dutch conflict of laws doctrine. ${ }^{\mathrm{xl}}$ In his famous work, "De Conflictu Legum" (1678) Huber quoted Sande more often than other authors and expressed his agreement with Sande's opinion (likely because Sande, as a fellow countryman was a lecturer at a university in Huber's favorite city of Franeker). Scottish students studying law in Dutch universities in the $17^{\text {th }}$ century brought Huber's theory to the British islands where it became the basis for conflict rules. However, Huber came up with and developed his thoughts that Sande had previously expressed. Sande's approach to resolving conflict of law greatly influenced Huber and laid the foundation for his theory. Thus, Sande's views were generally accepted by the modern Anglo-American conflict of laws community in part due to Huber. In "Decisiones aureae sive Frisiorum," Sande often referred to "Commentaries on the Legal Customs of Bretany" by the French jurist Bertrand d'Argentré who proposed division of all statues into three classes, personal, real, and mixed. He also defended the absolute territoriality of all legal customs. In conflict of laws doctrine, it was repeatedly stated that the theory of d'Argentré was successfully accepted in the Netherlands. ${ }^{x l i}$ However, Joannes à Sande doesn't mention the division of statues into three classes as all of his predecessors had done and only separates personal and real statues. Sande claims the imperative that "all legal customs are real," but this imperative was also stated by his fellow countrymen Nicolas Everhard and Pieter Peck, who were not acquainted with the theory of "the commentator of Bretton." In this regard, it seems logical to assert that the territorial approach to conflict of laws resolution in Sande's work was formed without influence from d'Argentré and that the strict territorialism of the "Belgian realists" corresponded with the requirements of the historical reality and formed independently.

In his book, Sande pays significant attention to questions of civil procedure. The jurisdiction of the Friesland court extends over people who do not reside in Friesland if the people voluntarily accept the competence of the court. Thus, Sande proposed the ability of forum prorogatum $^{\mathrm{xlii}}$. In issues of applicable procedural law, Sande adhered to the well-known at the time principle that during court proceedings, the law of the place where the claim was brought shall be applied even relative to contracts concluded in another place. The main reason for this is that the statute of limitations and performance of a contract relates not to the essence of the contract but to the method of hearing the case. A claim in and of itself is a quasi-contract and

\section{xxxix Ibid. P. 437.}

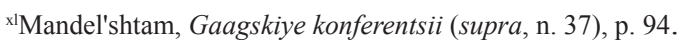

${ }^{x l i S e e ~ f . ~ e .: ~ L u n t s, ~ K u r s ~ m e z h d u n a r o d n o g o ~(s u p r a, ~ n . ~ 2), ~ p . ~} 127$

xliiSee: Gutzwiller, Geschichte (supra, n. 7), S. 129 separate transaction. ${ }^{\text {xliii }}$ The execution of judgements delivered abroad will always be governed by the law of the place where the execution is aught, not where the decision was delivered. The evaluation of a claim as an independent transaction, and the performance of a contract as the method for considering the claim corresponded with the expectations of the Dutch bourgeoisie of the time who were interested in the application of Dutch justice and law to their "foreign" transactions. Sande "in passing" noticed that a contract, which came into force in accordance with the law of the place it was concluded, also extends its effect to property located in another country. ${ }^{\text {xliv }}$

From Sande's point of view, the form of a legal act is undoubtedly subject to the law of the place where the act is formed, i.e. the possible application of foreign law. This international rule is an exception to the general territorial rule. At the same time, Sande as a realist "is totally alien to the idea that a foreign lex loci actus might conflict with the sovereignty of a judge or state of the country court". ${ }^{\mathrm{xlv}}$ At the same time, the scholar had begun to independently position the formal statue constituting a third group of statues. Sande joined Charles du Moulin's assertion that a legal act, which must be observed at the place it was completed, shall apply abroad as well. ${ }^{\text {xlvi }}$

In issues of resolving conflicts related to personal property, Sande supports the "ancient" concept that personal property is subject to the personal law of its owners (mobilia personam sequuntur). He also accepted and interpreted d'Argentré's view that personal property was fixed to its owner and that they are part of his personal status. Sande explains his position using the following example, stating that Frisian spouses would remain separate owners of property, even if it was located in the Netherlands because this is what the custom of Friesland provides. When Frisian spouses move from one province to another, the property, which then may move to one of them, will not be common property, and will remain separate property (as required by the custom of Friesland). The property, which was common property before the move, would retain its legal status that it originally had according to the personal law of the spouses. ${ }^{x l v i i}$ The same holds true for succession, if the property is located in various parts of the country, then the law of the domicile of the testator applies to personal or movable property. There are two basic principles in inheritance, inherited property is determined by the law of the location of the property and the ability to inherit is determined by the law of the most recent place of residence. These two principles of inheritance law at the time were strongly endorsed in the North Netherlands and evident in the works of all Dutch authors of the time. ${ }^{\text {xlvii }}$ These connecting factors are common to both inheritance with and without a will. The figure of Joannes à Sande completes the theory of Belgian realism and marks a move to the classical Dutch "international comity" doctrine. Sande departs from the Belgian extreme realism and allows extraterritoriality; the application of foreign law at home and the extension of personal law abroad. However, the strict real character of all legal customs collides with the personal statute and the extent of its effect abroad. It is necessary to explain why the legislator forbids

\footnotetext{
xliii See: Ernest G. ${ }^{13}$ Lorenzen, Huber's de conflictu legume, Illinois Law Review 13 (1918-1919), p. 233.

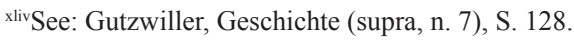

xlv Ibidem.

xlviSee: Gamillscheg, Der Einfluss Dumoulins (supra, n. 24), S. 153.

xlviiSee: Lorenzen, Huber's de conflictu (supra, n. 43), p. 208.

xlviiiSee: Gutzwiller, Geschichte (supra, n. 7), S. 128.
} 
extraterritoriality of the personal statute and allows the use of foreign law within its jurisdiction. Neither Sande nor his predecessors, the representatives of the Belgian realism formulated this explanation. It was developed by their followers, the Dutch scholars of the second half of the 17th century Ulrich Huber, and Paul and John Voet.

\section{Conclusion}

The Belgian realism theory formed within the conflict of laws doctrine over the course of the $16^{\text {th }}$ century and which gained legislative status in the Perpetual Edict, a Decree of the Archdukes Albert and Isabella in 1611. The strongest conflicts always arose in questions of inheritance law and legislative particularism intensified the conflict between the personal status of the testator and the status of the location of the property if the inherited property was located in different provinces. The Perpetual Edict was the result of the work of Belgian and Dutch jurists and completely destroyed the "personalization" of laws and reinforced their proprietary nature: "As soon as the testator's place of residence and the location of property was decided by the customs, the provisions of which are different to the testamentary dispersions, we rule onward that the status of the said property, the possibility to apply them, the proper age, and notarial form, to act according to the custom(s) of the location of the property (Article 13)". xlix The Edict was created exclusively under the influence of the Belgian realism theory and was an extreme expression of the tendency to consider the location of the property first ${ }^{1}$

Article 13 of the Edict required conformity of the custom of the property location with age, i.e., capacity, the condition of the property, the right to will it, and the form of the will. In the Edict under "notarial form," the rules for notarial acts were understood to ensure free expression of the testator in a will (the presence of a notary, the required number of witnesses, and the formal requirements for the text of the will). The Edict assumed that notarial acts prescribed by the personal status of the testator would differ from the acts prescribed by the status of the location of their property and made a choice in favor of the later. This absolute materiality of the customs contradicted the already well-established and recognized general principles of law, especially the principle of "locus regit actum," according to which the form of a legal act does not depend on the status of domicile or on the location of the property and is subject to the law of the place where the act was made.

The approach of the Perpetual Edict ruled out any possibility of extraterritorial effects of laws and the application of foreign law. This did not comply with the requirements of objective reality nor the aspirations of the Dutch provinces themselves who were interested in the fact that the subjective rights legally acquired on their territory and recognized abroad. Claiming that "all customs are real," representatives of Belgian realism by no means were "legal chauvinists," they all recognized the extraterritorial nature of personal status that did not affect property issues and they actively advocated applying the law of the place where the act was concluded for legal transactions (including wills). In addition, municipal and provincial courts often turned to foreign laws as trade relations of the time demanded relations with countries abroad..$^{\text {li }}$ At the insistence of Belgian jurists in 1634, a Decree of the Privy Council was issued xlix Cit.: Laurent, Droit civil international (supra, n. 15), p. 433.

'See: Brun, Ocherki istorii (supra, n. 17), p. 82.

liSee: Pierre Arminjon. Précis de Droit international privé, ed. Dallaz, Paris 1925, p. 40. containing an "authentic interpretation" of the Edict, which marked its abolition in the sense that the legal requirements of the location of property no longer applied when forming a will. ${ }^{\text {lii }}$

The reason for abolishing the provisions of the Edict with regard to the form of a will became a specific court case. Don Jerome del Posso composed a will in Brussels in 1619 in the presence of a notary and two witnesses in Milan where he himself was born and his property located. The will was contested on the basis of Article 13, which required compliance with the notarial form accepted in the place where the property was located: according to the statute of Milan, for a will to be valid, the presence of 7 witnesses was required. The plaintiff argued that the interpretation of the Edict of 1611 given by the Senate of Milan was false and asked for "authentic interpretation." The Decree of 1634 stated: "The provisions of Article 13 in no way can be attributed to the order assumed during preparation of a will, constituting evidence of its validity or safeguarding the true will of the testator; it distributes its power solely through notarial actions, clarifies the essence of testamentary disposition, without which disposal is impossible. liii Under the procedure relied upon in the preparation of a will, we understand the requirements of the testator's age and the contents of the will. The form of the will must comply with the custom of the place where it was composed or the laws of the Edict; the will of a testator concerning ownership and disposition of foreign real estate could have been legalized in Belgium in the form prescribed by local law. ${ }^{\text {liv }}$

The Decree of 1634 generalized the doctrine of Belgian realism which can be reduced to the following postulates:

Statues are separated into two classes, personal and real. Statues are only valid on the territory of the legislative body, which created them; on that territory, they are mandatory for all, citizens and foreigners alike. Personal statues define the status of a person without affecting property. Personal statues concerning exclusively non-property rights may follow a person abroad. Movable property is attached to a person and follows their status. All statues whether they concern property or not have a tangible character (property only refers to real estate). Real statues are absolutely imperative on their territory; they determine the fate of any property located there, even belonging to foreign citizens. The form of legal acts is subject to the law of the place where the acts were completed. None of the representatives of the theory of Belgian realism, not Nicolas Everhard, not Pieter Peck, and not Johannes a Sande attempted to create a general theory to resolve conflict of laws. Being both academic scholars and practitioners, they looked at conflict incidents from a purely practical position. The scholars argued in line with the already established theory of the time stipulating two classes of statues, arguing that as a general rule, all customs are real. The application of foreign law can have a place only in issues related to a person's status if these issues are not in any way connected with property. The Belgian realists were under the territoriality of the generally accepted legal opinions of the time, "inclined to vigilantly monitor the absolute value of the local law". lv

However, it is impossible to say that Everhard, Peck, and Sande did not play a positive role in the development of the doctrine of

\footnotetext{
liiSee: Lorenzen, Huber's de conflictu (supra, n. 43), p. 206

liii Cit.: Laurent, Droit civil international (supra, n. 15), p. 433.

livSee: Laine, Introduction au droit (supra, n. 8), p. 400-401.

${ }^{1}$ Boris Nol'de, ${ }^{15}$ Ocherk mezhdunarodnogo chastnogo prava, in: Mezhdunarodnoye pravo, ed. Franz von Liszt, St. Petersburg 1912, p. 371-403.
} 
PIL. They formulated connecting factors perceived by lawmakers today; their research served as the basis for the emergence of the Dutch classical doctrine of international comity, which became the underlying theory of the Anglo-American conflict of laws. Their names are undeservedly forgotten, and in the history of the science of PIL there should not be gaps. The work of all of the representatives of the theory of statues was the commanding idea for over 500 years in the doctrine of conflict of laws and it certainly deserves study and thought.

\section{Acknowledgements}

None.

\section{Conflict of interest}

None.

\section{References}

1. Lasar' Lunts. Kurs mezhdunarodnogo chastnogo prava. Moscow: Spark; 2002. $1062 \mathrm{p}$.

2. Pierre Arminjon. Précis de Droit international privé. Paris: Dalloz; 1925. $72 \mathrm{p}$.

3. Alexander Merezhko. Nauka mezhdunarodnogo chastnogo prava: istoriya i sovremennost. Kiev: Takson; 2006. 354 p.

4. Christian von Bar u, Peter Doppel, Mitw V, Hans J Hilling. Deutsches Internationales Privatrecht im 16. und 17. Jahrhundert. Band 2: Materialien, Übersetzungen, Anmerkungen. 2001. 758 p.
5. Max Gutzwiller. Geschichte des International privatrechts. Helbing, Lichtenhahn, editors. Stuttgart: Rechtsfragen der Inflation publishers; 1977. p. 311-326.

6. Armand Laine. Introduction au droit international privé. TIP: Librairie cotillion F Pichon; 1888. 427 p.

7. Bertrand Ancel. Histoire du droit international privé. Paris: Université Panthéon-Assas (Paris II); 2008. 196 p.

8. Francois Laurent. Droit civil international. TI Bruxelles: BruylantChristophe \& ce, 1880. 668 p.

9. Michail Brun. Ocherki istorii konfliktnogo prava. Moscow: Lissnera i D Sobko publisher; 1915. $105 \mathrm{p}$.

10. Friedrich Meili. Civil- und Handelsrecht auf Grund der Theorie, Gesetzgebung und Praxis. Zurich: Institut Orell Fussli; 1902. 405 p.

11. Franz Gamillscheg. Der Einfluss Dumoulins auf die Entwicklung des Kollisionsrechts. Tubingen: De Gruyter, Mohr; 1955. p. 268-272.

12. Joseph Story. Commentaries on the Conflict of laws, foreign and domestic. Boston: Hilliard, Gray, and Company publishers; 1834. 557 p.

13. Ernest G Lorenzen. Huber's de conflictu legume. Illinois Law Review. 1919;13(1):375-418.

14. Andrey Mandel'shtam. Gaagskiye konferentsii o kodifikatsii mezhdunarodnogo chastnogo prava. Russia: TI St. Petersburg; 1900. 483 p.

15. Boris Bruck. Galina Shatokhina-Mordvintseva. Istoriya Niderlandov. Moscow: Drofa; 2007. 511 p. 